\title{
Optimal International Reserves in Lesotho
}

\author{
Senei Solomon Molapo
}

Central Bank Of Lesotho, Lesotho, Economist, Research Department

doi: 10.19044/esj.2016.v12n13p282 URL:http://dx.doi.org/10.19044/esj.2016.v12n13p282

\begin{abstract}
Literature has addressed the issue of choosing reserves levels in the context of models based on traditional adequacy ratio. Above that, this study employs the model of Jeanne and Rancière (2006), which captured the unique characteristics of a country, and effects of a small and large external shocks portrayed that international reserves in Lesotho are kept at level higher than the optimum level. The results outlined that optimum level of reserves for Lesotho is on average 44 per cent of GDP for a small crisis and 47 per cent of GDP for a larger crisis. Subsequently, this leads to the conclusion that the amount of reserves exceeding the level of backing assets could be managed under a more return-oriented investment strategy in order to minimize the opportunity cost of reserves holding. Since there is evidence of excess funds, the authorities should strengthen the implementation capacity of the annual capital budgets by evolving a forceful and vigorous monitoring and evaluation framework in order to accomplish the National Vision 2020 goals. This will also create an opportunity to allocate resources to the National Strategic Development Plan (NSDP) which provides overall national strategic thrust from 2012 to 2016.
\end{abstract}

Keywords: International Reserves, Reserve Adequacy, Optimal, Lesotho

\section{Introduction}

The IMF (1993) postulates that international reserves (IR) are those external assets that are readily available to and controlled by the monetary authorities for direct financing of payments imbalances through intervention in exchange markets to affect the currency exchange rate, and/or for other purposes. The IR should include convertible foreign exchange held by monetary authorities in the form of currency, deposit, securities or financial derivative, monetary gold, special drawing rights, and unconditional drawing rights with the IMF.

The existing literature outlines various objectives for the IR holding. These motives are commonly allocated in two components, namely precautionary and mercantile motive (Aizeiuman and Marion, 2003; Kim et 
al, 2005; Aizenman and Lee, 2005). The precautionary motive outlines that the economies with a high degree of openness use IR as shock absorber when they come across random shocks to their external balance. Second, countries which borrow heavily abroad to finance BOP deficits, IR informally carry out the function of collateral for external liabilities under the precautionary motive De Beaufort Wijnholds and Kapteyn (2001). Third, for small economies those are in a process liberalising their external accounts, IR play a role in enhancing confidence in national currency.

On the other hand, there is a high degree of risk involved in holding large IR. An appreciation of domestic currency against major currencies possesses risk of loss of the value of IR. The second risk involves owning sterilised purchases of reserves where domestic assets of the economy may fall to low levels due to central bank issuing new liabilities since there is no clear limit of the extent of sterilization. The third risk is the opportunity cost of holding IR. According to Green and Torgerson (2007), the resources used to purchase IR could be used in a number of alternative ways such as paying down sovereign short term debt, and spending on investment projects.

For years, the cumulative growth in the IR in Lesotho has risen from 1.3 billion in 1982 to 8.5 billion in 2012. At the end of 1998, the IR totaled nearly M3.5 billion, compared to M3.3 billion at the end of 1999, representing an annual decline of 5.6 per cent. The IR rose sharply between the early part of 2005 and 2008, reaching a high of 9 billion in 2008. Then, the IR came under severe pressure, registering a decline of 7 and 19 per cent in 2009 and 2010 respectively, a drawdown due to the aftermath of 2008 economic and financial meltdown. However, in 2011, IR reached 7.3. This circumstance has provided the opportunity to ask a number of questions regarding the adequate and optimal level of reserves in Lesotho. Are there any excess reserves in Lesotho and what are their costs?

Figure 2.1 International Reserves (million Maloti)

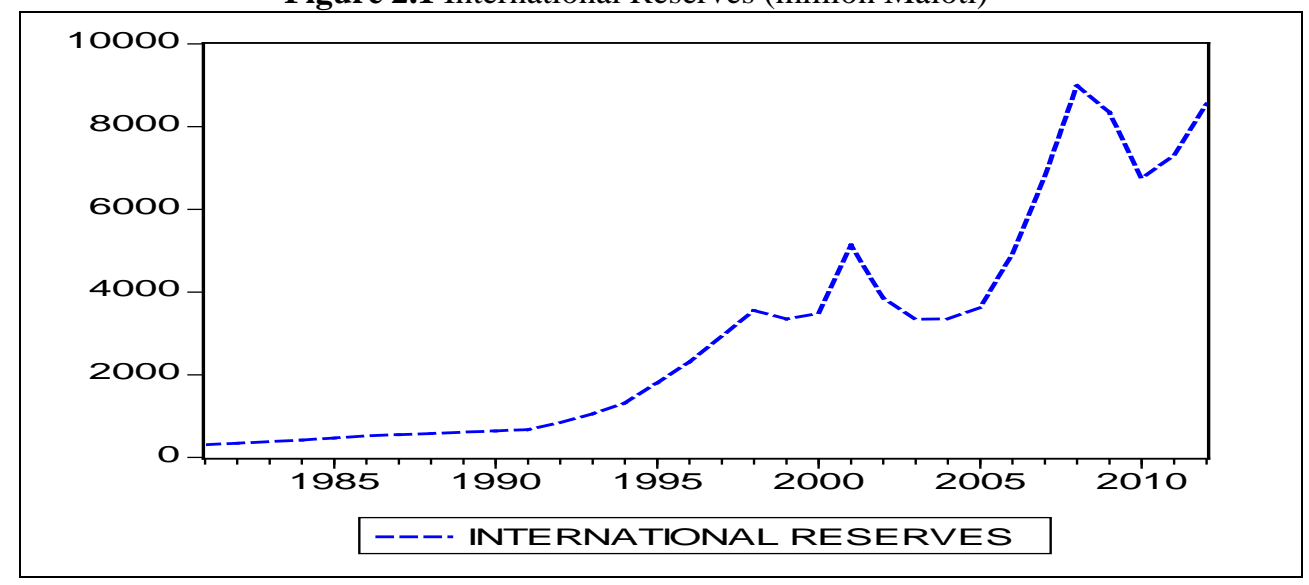

Sources: Central bank of Lesotho 
It is alongside this background that this study investigates the optimal level of IR in Lesotho. In addition to the use of the traditional benchmarking ratios, this paper adopts the model of Jeanne and Rancière (2006) of optimal level of IR for a small open economy that is vulnerable to sudden stops in capital flows. In the model, IR allowed the country to smooth domestic absorption in response to sudden stops, but yielded a lower return than the interest rate on the country's long-term debt. There are studies such as Triffin (1946), Heller (1966) and IMF (2002) which provide the empirical investigation of the optimum level IR. The advantage of Jeanne and Rancière (2006) measure is that it decomposes the reserves into a component that can be justified as an insurance against sudden stops. This will give the authorities a benchmark for alternative use of excess IR such as the funding in development projects which can yield higher return on IR. On the other hand, the authorities can work on building IR as a self-insurance strategy in the case of inadequate IR.

The rest of the paper is structured as follows: the next section provides Lesotho's brief economic background. Section three reviews the relevant literature on optimal IR. Section four explains the methodology, while section five presents the outcomes. The last section summarizes the main findings and concludes the study.

\section{Literature Review}

The exchange rate policy is an important determinant underpinning the considerations of the need for a country to hold IR. For day-to-day transactions together with debt repayments, payments to international organizations, and payments for imports, a country may require small amount of foreign currency reserves. Countries with exchange rate peg such as Lesotho need to hold reserves to offset adverse pressure on their currencies. Even economies with flexible exchange rates hold some reserves in order to intervene in foreign exchange markets to avoid a disorderly depreciation of their currency. Governments also hold reserves to provide a defence against substantial and rapid capital outflows that could result in a loss of investor confidence and a currency crisis. This self-insurance motive has received the most attention in recent years and is often seen as one reason for the intensification in global reserves since the financial crises of the late 1990s. Fischer (2001) emphasised the usefulness of foreign reserves as a tool to avoid crises, but there is a limit to the amount of foreign reserves needed to prevent the financial crisis, bearing in mind that holding large foreign reserves can indicate costs. Consequently, there are some common indicators that are used to determine the adequate level of foreign reserves for an economy. 
According to a number of studies including IMF (2003), De Beaufort Wijnholds and Kapteyn (2001), Bird and Rajan (2003), Kim et al (2005), the reserves in many countries undoubtedly exceed any benchmark level for financial safeguard against sudden shock. This results in several questions which still remained on the rationale behind recent large reserve hoarding such as, what is the optimum level of reserves? Standard literature alludes to 3 measures used to benchmarking the adequacy of IR. According to Rodrik and Velasco (1999), a country is considered prudent, if it holds foreign reserves in the amount of its total external debt maturing within one year. The reserves to short-term debt measure have been evidenced empirically relevant to currency crisis prevention.

Recent studies on analysis of optimal reserves such a Durdu (2009), presents some estimates of the optimal level of precautionary savings accumulated by a small open economy in response to business cycle volatility, financial globalization, and the risk of sudden stop. The study concludes that financial globalization and the risk of sudden stop may be plausible explanations of the observed surge in reserves in emerging market countries. The second model is the one of Jeanne and Rancière (2006) which is one of insurance, rather than precautionary savings, and further Caballero and Panageas (2007). Caballero and Panageas (2007) calibrated a dynamic general equilibrium model in which the country that is vulnerable to sudden stops can invest in conventional reserves as well as more sophisticated assets whose payoffs are correlated with sudden stop arrivals. They found that the gains from the optimal hedging strategies can be substantial.

\section{Methodology}

\section{Adequacy Ratios}

The paper starts by determining the adequate IR in Lesotho. Triffin (1946), IMF (2002, 2003) and Heller (1966) among others noted that the models which assume optimal reserves should be that which could finance the gap between demand and supply of foreign currency, smoothen external payments imbalances and prevent exchange rate crisis. In principle, the adequacy of reserves is assessed by their capacity to prevent or mitigate external shocks. The following are various traditional metrics approaches to reserve adequacy as provided by literature:

\section{Import cover}

The most prominent factor is the ratio of foreign reserves to imports (import cover). This represents the number of months of imports for which a country could support its current level of imports, if all other inflow and outflow stops. The ratio has been used as a standard measure of reserves adequacy since the 1960s and postulates that the demand for reserves could 
normally be expected to grow in line with international trade (Triffin 1946). According to the IMF (2000), a rule of thumb, countries are to hold reserves in order to cover their import for three to four months. The import cover is assumed to take the following form:

$$
R A_{t}=I R_{t} / T I_{t} \text {, }
$$

where $R A_{t}$ is reserve adequacy at time t, $I R_{t}$ is IR at time $\mathrm{t}$ and $T I_{t}$ is total imports at time t.

\section{International Reserves as a ratio of short-term debt}

Greenspan (1999) advocated for the size of the reserves of emerging market economies that is related to their short-term external debt outstanding. This is a new minimum reserves stock benchmark using shortterm emerging market debts as well as the current account deficit as a measure of reserves adequacy. The short-term debt outstanding should be of maturity less than one year. Then IR as a ratio of short-term debt is given by

$$
R A_{t}=I R_{t} / S T D_{t} \text {, }
$$

where $R A_{t}$ is reserve adequacy at time $t, I_{t}$ is IR at time $t$ and $\operatorname{STD}_{t}$ is short term debt at time t. In support of equation 2, IMF (2009) recommended that IR should be equivalent to all external assets controlled by the monetary authorities, undrawn, unconditional external credit lines should be included as IR and the definition of official reserve assets should only cover the total amount of immediately available liquid external assets that can answer to the demands of the short term creditors.

\section{International Reserves as a ratio of broad money (M2)}

Kaminsky and Reinhart (1999) employed the monetary aggregates and measured reserves adequacy as the ratio M2. They considered this ratio as an accurate predictor of crises. De Beaufort Wijnholds and Kapteyn (2001) also revealed the monetarist approach to reserves adequacy by linking reserves to broad money. Increased money stock was expected in an importdependent economy to translate to increased imports which would drain the reserves. Given that many recent capital account crises have been accompanied by outflows of deposits of domestic residents, this metric is usually intended to capture this risk of capital flight. The ratio of IR to M2 is given as follows:

$$
R A_{t}=I R_{t} / M 2_{t}
$$

where $R A_{t}$ is reserve adequacy at time $t, R_{t}$ is international reserves at time $\mathrm{t}$ and $\mathrm{M} 2_{\mathrm{t}}$ is broad money at time $\mathrm{t}$.

\section{Optimal international reserves}

The traditional metrics approaches discussed in the previous section can be criticised for lacking microfoundations and empirical evidence. This 
section presents Jeanne and Rancière (2006) model of the optimal level of reserves. The model looks at the intertemporal optimization problem of the government in a small open economy that is hit by sudden stops in capital flows associated with a fall in output. The cost of holding reserves is that they yield a lower return than the interest rate that the government must pay on its long-term external liabilities. But the main benefit of reserves is to allow the government to smooth domestic absorption in crises where the real domestic absorption in an open economy can be written as follows.

$$
A_{t}=Y_{t}-T B_{t} \text {, }
$$
be written as,

where $A_{t}$ is absorption, $Y_{t}$ is output and $T B_{t}$ is trade balance and can

$$
T B_{t}=-K A_{t}-I T_{t}+\Delta \mathrm{R}_{t},
$$

where $K A_{t}$ is capital or financial account, $I T_{t}$ is income and transfers from abroad and $\Delta \mathrm{R}_{t}=\mathrm{R}_{t}-\mathrm{R}_{t-1}$ is change in reserves. By combining equation (4) and (5) the following expression is found.

$$
A_{t}=Y_{t}+K A_{t}+I T_{t}-\Delta \mathrm{R}_{t}
$$

A sudden stop in capital is an abrupt fall in the primary income account. According to Jeanne and Rancière, there is a sudden stop if the ratio of capital inflows to GDP (k) falls by more than 5 per cent relative to the previous year: $k_{t}<k_{t-1}-5 \%$ which can also be accompanied by a fall in output, $Y_{t}$. The model also divides the domestic economy into private sector and the government where the domestic private sector is assumed as a representative consumer who is subject to the following budget constraint.

$$
C_{t}=Y_{t}+L_{t}-(1+r) l_{t-1}-\mathrm{Z}_{t} \text {, }
$$

where $C_{t}$ is consumption, $L_{t}$ is the foreign debt of the representative consumer and $\mathrm{Z}_{t}$ is a transfer from the government. The interest rate $\mathrm{r}$ is constant, and the representative consumer does not default on external debt. When the sudden stop occurs, two things happen: the representative consumer is unable to roll over her external debt, and output falls by a fraction $\gamma$ below its long-run growth path. Since the consumer's external debt is short-term, this implies that $\mathrm{L}$ falls to zero in a sudden stop. After the sudden stop, private external debt remains equal to zero, and output goes back to its long-run growth path. The probability of crisis, which is assumed to be the like hood occurrence of a sudden stop, is denoted by $\pi$ in each period. After the sudden stop, all the uncertainty is resolved, and the economy grows at rate $\mathrm{g}<\mathrm{r}$.

$$
\begin{array}{r}
\mathrm{Y}_{\mathrm{t}}^{\mathrm{b}}=Y_{t}^{a}=(1+g)^{t} Y_{0}, \mathrm{Y}_{\mathrm{t}}^{\mathrm{d}}=(1-\gamma)(1+r)^{t} Y_{0}, \\
L_{t}^{b}=\lambda(1+g)^{t} Y_{0}, \mathrm{~L}_{\mathrm{t}}^{\mathrm{d}}=\mathrm{L}_{\mathrm{t}}^{\mathrm{a}}=0,
\end{array}
$$

where respectively superscripts $b, d$, and a, denote with the periods before, during, and after the sudden stop and $\lambda$ is the level of private external debt as a share of output in the pre-sudden-stop period. The government, 
unlike the private sector, can issue a long-term security that does not have to be repaid in a sudden stop. This is a bond that yields one unit of good in every period until the sudden stop occurs. The security stops yielding any income after the sudden stop. The government security has a long maturity in the sense that its life expectancy, $1 / \pi$, is large if $\pi$ is small. In this case since $\pi=10$ per cent the life expectancy of the security is ten years.

The pre-sudden-stop price of the security $(\mathrm{P})$ is equal to the present discounted value of the one unit of good it pays in the next period (with certainty) plus the expected market value of the security as shown below.

$$
P=\frac{1}{r+\delta+\pi}
$$

To finance the stock of reserves, the government issues the long term security as shown:

$$
R_{t}=P N_{t}
$$

where $N_{t}$ is the number of securities issued by the government. Using this fact the following expression can be derived.

$$
Z_{t}+R_{t}+N_{t-1}=P\left(N_{t}-N_{t-1}\right)+(1+r) R_{t-1},
$$

From equation 12, an expression for the transfer before the sudden stop can be derived as follows.

$$
Z_{t}^{b}=-\left(\frac{1}{P}-r\right) R_{t-1}=-(\delta+\pi) R_{t-1}
$$

With the assumption that $\delta+\pi<1$ which ensures that government transfer is positive, then the government becomes inactive after the sudden stop: $R_{t}, N_{t}$ and $Z_{t}$ are all then equal to zero. Substituting equations (12) and (13) into equation (7) yields the following expressions for the level of domestic consumption respectively before, during, and after the sudden stop.

$$
\begin{aligned}
& C_{t}^{b}=Y_{t}^{b}+L_{t}^{b}-(1+r) L_{t-1}^{b}-(\delta+\pi) R_{t-1} \\
C_{t}^{d}= & (1-\gamma) Y_{t}^{b}-(1+r) L_{t-1}^{b}+(1-\delta-\pi) R_{t-1} \\
& C_{t}^{a}=Y_{t}^{a}
\end{aligned}
$$

Equation (14), (15) and (16) outlines the stylized facts about IR, in particular the fact that reserves help the government smooth domestic absorption in response to a sudden stop. To close the model the following government's objective function is specified in which the government is assumed to maximise the welfare of the representative consumer subject to constraint equations (14), (15) and (16).

$$
U_{t}=\sum_{s=0, . .+\infty}(1+r)^{-s} U\left(C_{t+s}\right),
$$

The utility function has a constant relative risk aversion $\sigma$,

$$
u(C)=\frac{C^{1-\sigma}-1}{1-\sigma}
$$

The government's problem is to find the level of reserves $R_{t}$ that maximizes $U_{t}$ in each period t before the sudden stop occurs. In brief, $R_{t}$ matters only for the level of consumption in $t+1$. The optimal level of 
reserves in period $t$ maximizes the expected utility of period $t+1$ consumption as shown in equation 17 below.

$$
R_{t}=\arg \max (1-\pi) u\left(C_{t+1}^{b}\right)+\pi u\left(C_{t+1}^{d}\right)
$$

The first-order conditions are as follows;

$$
\pi(1-\pi-\delta) \mathrm{u}^{\prime}\left(C_{t+1}^{d}\right)=(1-\pi)(\delta+\pi) \mathrm{u}^{\prime}\left(C_{t+1}^{b}\right)
$$

The left-hand side of the first order condition shows the probability of a sudden stop times the marginal utility of reserves during a sudden stop. The right-hand side of the first order condition shows the probability of no sudden stop times the marginal cost of reserves before a sudden stop. This first-order condition can be manipulated to obtain a closed-form expression for the optimal level of reserves. By denoting $p_{t}$ as the marginal rate of substitution between consumption in the sudden-stop state and consumption in the non-sudden-stop state the formula becomes,

$$
P_{t}=\frac{u^{\prime}\left(C_{t}^{d}\right)}{u^{\prime}\left(C_{t}^{b}\right)}
$$

By combining equation (20) and (19) yields the following expression.

$$
p \equiv \frac{1-\pi}{\pi} \frac{\delta+\pi}{1-\delta-\pi}=1+\frac{\delta}{\pi(1-\delta-\pi)}
$$

If the term premium $\delta$ is equal to zero, then $\mathrm{p}$ is equal to 1 , implying that domestic consumption is perfectly insured against the risk of a sudden stop ( $C_{t}^{d}=C_{t}^{b}$ ). If the term premium is strictly positive, then $\mathrm{p}$ is larger than 1 , implying that domestic consumption is lower in a sudden stop ( $C_{t}^{d}<C_{t}^{b}$ ). From the first-order condition, optimal level of reserves in normal times is a fixed fraction of the level of output as shown below.

$$
R_{t}=\rho Y_{t+1}^{b}
$$

where the optimal reserves-to-output ratio $\rho$ is given by,

$$
\rho=\lambda+\gamma-\frac{\mathrm{p}^{\frac{1}{\sigma}-1}}{1+\left(\mathrm{p}^{\frac{1}{\sigma}-1}\right)(1-\delta-\pi)}\left(1-\frac{r-g}{1+g} \lambda-(\delta+\pi)(\lambda+\gamma) \dot{\gamma}\right.
$$

Equation (23) is the formula for the optimal level of reserves in this model. By setting $\delta+\pi=\mathrm{r}-\mathrm{g}=0$ in the last term of equation (23), an approximation to the exact formula can be obtain as follows.

$$
\rho \approx \lambda+\gamma-\left(1-\mathrm{p}^{-\frac{1}{\sigma}}\right)
$$

Equation (24) shows that the optimal level of reserves is increasing one for one with the amount of short-term debt and the output cost of a sudden stop. As noted earlier, if the term premium $\delta$ is equal to zero, then $p$ is equal to 1 , and reserves should be set to the level that perfectly smoothes the impact of the sudden stop on domestic consumption, $\rho=\lambda+\gamma$. The optimal level of reserves falls with an increase in p, which in turn could be caused by a decrease in the probability of a sudden stop, $\pi$, or an increase in 
the term premium, $\delta$. An increase in the risk aversion parameter $\sigma$ decreases $\mathrm{p}^{\frac{1}{\sigma}}$ and raises the optimal level of reserves.

\section{Data and Results}

\section{Data Description}

The paper uses annual time series data sourced from Central Bank of Lesotho and publications of the Bureau of Statistics Lesotho. It is quantitative and secondary in nature. Based on the empirical and theoretical frameworks, most relevant estimates are incorporated in the model where data is unavailable.

\section{Test Results for Adequate Level of International Reserves Reserves to Three Months of Import}

The rule of thumb is that the stock of reserves should equal three months of imports. When evaluating equation 1 from 2003 to 2012, the results show the adequate reserves and excess reserves for Lesotho are calculated. The results show that IR in Lesotho reached, on average, 49 per cent of GDP, while adequate reserves are only 29 per cent of GDP on average 20 percentage points about the rule of thumb.

\section{Reserves to Broad Money (M2)}

The next benchmark ratio is the reserves to M2 ratio. Using equation 3 , total reserves for Lesotho according ranged on average 49 per cent of GDP, of which adequate reserves constitute 35 per cent of GDP. The ration suggests that international reserves amounting to 14 per cent of GDP on average, were excess in that period.

\section{Optimal Level of International Reserves}

To ascertain the optimal IR, the model of Jeanne and Rancière (2006) is used. The model is calibrated using the role of reserves inferred from a few accounting relationships. Using equation (21) and (24), the benchmark calibrations are show in table A1. 
Table 4.4: Actual and Optimum Reserves of Lesotho, Jeanne and Ranciere Model for a Small Crises

\begin{tabular}{|c|c|c|c|c|c|c|}
\hline \multirow{2}{*}{$\begin{array}{l}\text { Year } \\
2003\end{array}$} & \multicolumn{2}{|c|}{$\begin{array}{c}\text { International } \\
\text { Reserves } \\
\boldsymbol{I R}_{\boldsymbol{t}} \\
\end{array}$} & \multicolumn{2}{|c|}{$\begin{array}{l}\text { Adequate } \\
\text { Reserves } \\
\boldsymbol{A R}_{\boldsymbol{t}} \\
\end{array}$} & \multicolumn{2}{|c|}{$\begin{array}{c}\text { Excess Reserves } \\
\qquad \boldsymbol{I}_{\boldsymbol{t}}-\boldsymbol{A} \boldsymbol{R}_{\boldsymbol{t}} \\
\end{array}$} \\
\hline & 3341 & (46\%) & 4387 & $(60 \%)$ & -1046 & $(-14 \%)$ \\
\hline 2004 & 3352 & $(42 \%)$ & 3270 & $(41 \%)$ & 81 & $(1 \%)$ \\
\hline 2005 & 3626 & $(42 \%)$ & 3431 & (39\%) & 195 & (2\%) \\
\hline 2006 & 4919 & (51\%) & 4953 & (51\%) & -34 & (0\%) \\
\hline 2007 & 6786 & $(60 \%)$ & 5760 & $(51 \%)$ & 1027 & (9\%) \\
\hline 2008 & 8989 & (67\%) & 6708 & $(50 \%)$ & 2281 & (17\%) \\
\hline 2009 & 8345 & (58\%) & 5681 & (39\%) & 2665 & (18\%) \\
\hline 2010 & 6750 & (42\%) & 6041 & (38\%) & 709 & (4\%) \\
\hline 2011 & 7298 & $(40 \%)$ & 7120 & (39\%) & 178 & (1\%) \\
\hline 2012 & 8545 & (45\%) & 7419 & (39\%) & 1126 & (6\%) \\
\hline
\end{tabular}

Source: own computations

Note: \% of GDP in parentheses

The results shown in table 5.1 indicate that IR in Lesotho reached on average 49 per cent of GDP, while optimal reserves are on average 44 per cent of GDP in that period. The excess reserves are on average 5 per cent of GDP which is significantly lower than the levels portrait by the traditional ratios. However the optimal levels were barely reached by Lesotho in 2003 and 2006, implying that, for those years, there were insufficient levels of reserves that could smooth consumption in the case of small crisis (IMF, 2009). Nonetheless, the authorities continued accumulating excessive level of reserves enough to smooth consumption in case of a crisis for other years within the sample, reaching an excess of 17 per cent of GDP in 2008. In 2010, the excess reserves declined to 4 per cent of GDP due to the aftermath of the 2008 US crisis. The indication is that, IR in Lesotho are accumulated in times of abundance and used in times of scarcity to reduce adjustment costs under non-reserves scenario (IMF, 2009).

The same calibration is done for a larger crisis which is depicted by the output cost of a sudden stop. The output cost of a sudden stop, $y$, is derived here also by taking the difference between the GDP growth rate in normal times and the growth rate in sudden stop which is 4.3 per cent for a larger crisis over the sample. The results, as shown in table 5.5, portray insufficient reserves for the years, 2003, 2004, 2006 and 2011 respectively. However, on average, the results show that IR holding in Lesotho is sufficient enough to sustain the economy against a large shock. 
Table 4.5: Actual and Optimum Reserves of Lesotho, Jeanne \& Ranciere Model for a Large Crisis

\begin{tabular}{ccccccc}
\hline Year & $\begin{array}{c}\text { International } \\
\text { Reserves } \\
\boldsymbol{I R}_{\boldsymbol{t}}\end{array}$ & \multicolumn{2}{c}{$\begin{array}{c}\text { Adequate } \\
\text { Reserves } \\
\boldsymbol{A R}_{\boldsymbol{t}}\end{array}$} & \multicolumn{2}{c}{\begin{tabular}{c}
$\boldsymbol{I R}_{\boldsymbol{t}}-\boldsymbol{A R}_{\boldsymbol{t}}$ \\
\hline
\end{tabular}} \\
& & & & & -1192 & $(-16 \%)$ \\
2003 & 3341 & $(46 \%)$ & 4534 & $(62 \%)$ & -78 & $(-1 \%)$ \\
2004 & 3352 & $(42 \%)$ & 3430 & $(43 \%)$ & 21 & $(0 \%)$ \\
2006 & 3626 & $(42 \%)$ & 3605 & $(41 \%)$ & -228 & $(-2 \%)$ \\
2007 & 4919 & $(51 \%)$ & 5146 & $(53 \%)$ & 802 & $(7 \%)$ \\
2008 & 6786 & $(60 \%)$ & 5985 & $(53 \%)$ & 2012 & $(15 \%)$ \\
2009 & 8989 & $(67 \%)$ & 6978 & $(52 \%)$ & 2374 & $(16 \%)$ \\
2010 & 8345 & $(58 \%)$ & 5972 & $(41 \%)$ & 386 & $(2 \%)$ \\
2011 & 6750 & $(42 \%)$ & 6363 & $(40 \%)$ & -189 & $(-1 \%)$ \\
2012 & 7298 & $(40 \%)$ & 7486 & $(41 \%)$ & 724 & $(4 \%)$ \\
\hline
\end{tabular}

Source: own computations

Note: \% of GDP in parentheses

\section{Conclusion}

IR holding is vital not only for shaping the monetary and exchange rate policy, but also in the context of increased interest in the subject and in the face of globalization of economies as well as integration of financial markets. The process of liberalization in Lesotho has been associated with an increased demand for IR and as such, a critical look at their impact is warranted. The findings of traditional adequacy ratios, import cover and reserves to M2, from 2003 to 2012 indicate that the authorities in Lesotho keep more IR than required. In line with these results, the model of Jeanne and Rancière (2006), which captured the unique characteristics of Lesotho, and effects of a small and large external shocks portrayed that, IR in Lesotho are kept at level higher than the optimum level. The results confirm that optimum level of IR in Lesotho is on average 44 per cent of GDP for a small crisis and 47 per cent of GDP for a larger crisis. The indication is that, IR in Lesotho are accumulated in times of abundance and used in times of scarcity to reduce adjustment costs under non-reserves scenario (IMF, 2009).

The utmost policy concern in Lesotho is the monetary stability under the fixed exchange rate system and guaranteeing the convertibility of all domestic monetary liabilities into foreign currencies. The continued accumulation of IR on top of optimum level reveal a prolonged imbalance in the Lesotho's BOP in the form of persistent large current account deficit, which is likely to stem from some structural factors in the economy such as decreasing production base as result of inability to utilize the budgeted development fund as suggested by Ministry of Finance (2012). Since there is evidence of excess funds, the authorities should strengthen the 
implementation capacity of the annual capital budgets in order to create an alternative use of excess IR. This can be achieved by evolving a forceful and vigorous monitoring and evaluation framework in order to accomplish the National Vision 2020 goals. This will also create an opportunity to allocate resources to the National Strategic Development Plan (NSDP) which provides overall national strategic thrust from 2012 to 2016.

\section{References:}

Aizenman, J., \& Lee, J. (2007). International reserves: precautionary versus mercantilist views, theory and evidence. Open Economies Review, 18(2), 191-214.

Aizenman, J., \& Marion, N. (2003). The high demand for international reserves in the Far East: What is going on?. Journal of the Japanese and International Economies, 17(3), 370-400.

Bank, L.C. (2011). Annual Report 2011.Central bank of Lesotho.

Bird, G., \& Rajan, R. (2003). Too much of a good thing? The adequacy of international reserves in the aftermath of crises. The World Economy, 26(6), 873-891.

Caballero, R. J., \& Panageas, S. (2007). A global equilibrium model of sudden stops and external liquidity management.

De Beaufort Wijnholds, J. A. H., \& Kapteyn, A. (2001). Reserve adequacy in emerging market economies (No. 143). International Monetary Fund.

Durdu, C. B. (2009). Quantitative implications of indexed bonds in small open economies. Journal of Economic Dynamics and control, 33(4), 883902.

Fund, I. M. (1993). Balance of Payments Manual. Washington: International Monetary Fund.

Fund, I. M. (2000), Annual Report. Washington, D.C.: International Monetary Fund.

Fund, I. M. (2002), Annual Report. Washington, D.C.: International Monetary Fund.

Fund, I. M. (2003), Are foreign reserves in Asia too high, World Economic Outlook, Chapter II, September 2003, 78-92.

Fund, I. M. (2009) International Financial Statistics. Washington, D.C.: International Monetary Fund.

Fund, I. M. (2009), Annual Report. Washington, D.C.: International Monetary Fund.

Government, L. (2012), Annual Report, 2012. Ministry of Finance, Government of Lesotho.

Green, R., \& Torgeson, T. (2007). Are high foreign exchange reserves in emerging markets a blessing or a burden?. United States Department of the Treasury. 
Hannoun, H. (2012). 20120216 Bank for International Settlements: Monetary policy in the crisis-testing the limits of monetary policy (Speech by Deputy General Manager. Korea.

Heller, H. R., \& Khan, M. S. (1978). The Demand for International Reserves under Fixed and Floating Exchange Rates. Staff Papers-International Monetary Fund, 623-649.

Heller, H. R., (1966). Optimal International Reserves. The Economic Journal, 76(302), 296-311.

Kaminsky, G. L. (1999). Currency and banking crises-the early warnings of distress. International Monetary Fund.

Kim, J. S., Li, J., Rajan, R., Sula, O., \& Willett, T. D. (2005). Reserve adequacy in Asia revisited: new benchmarks based on the size and composition of capital flows. In Claremont-KIEP Conference Volume on Monetary and Exchange Rate Arrangements.

Krugman, P. (1979). A model of balance-of-payments crises. Journal of money, credit and banking, 311-325.

Masenyetse, R. F., \& Motelle, S. I. (2012). Government RevenueExpenditure Nexus in Lesotho: the Decline in SACU Revenue. American Journal of Economics, 2(1), 8-14.

Molapo, S., \& Damane, M. (2015). Determinants of Private Investment in Lesotho. European Scientific Journal, ESJ, 11(34).

Ranciere, R., \& Jeanne, O. (2006). The optimal level of international reserves for emerging market countries: formulas and applications. International Monetary Fund.

Rodrik, D., \& Velasco, A. (1999). Short-term capital flows (No. w7364). National Bureau of Economic Research.

Sehgal, S., \& Sharma, C. (2008). A study of adequacy, cost and determinants of international reserves in India. International Research Journal of Finance and Economics, 20, 75-90.

Thamae, R. I. (2013). The growth of government spending in Lesotho. Economic Analysis and Policy, 43(3), 339.

Triffin, R. (1946). National central banking and the international economy. The Review of Economic Studies, 14(2), 53-75. 